\title{
Social Media Use During Social Gathering Among Youth: A Study on Moghbazar Area of Dhaka City
}

\author{
Md. Tahsinul Haque*, Eashrat Jahan Eyemoon, Arifur Rahaman \\ Department of Sociology, University of Dhaka
}

*Corresponding author email: tahsinhaque69@gmail.com

Received: 16 April 2021 / Revised: 19 July 2021 / Accepted: 03 August 2021 / Published: 21 August 2021

\begin{abstract}
The rise of social media and continuous technological advances have had a significant impact on how people communicate. Social media sites include social networking sites like Facebook, Instagram, and WhatsApp, and any website that allows social interaction. Many studies have been conducted on the impact of social media, but this study is specifically based on the impact of social media on social gatherings in Dhaka. The primary objective of this study is to examine how the virtual world reshapes the way of social gathering. In this study, an online survey was administered to find out the level of engagement of social media during a social gathering. The researcher collected a total of 120 respondents using the purposive sampling method. Findings suggest that social media intensely affects social gatherings. Despite respondents' awareness of the decrease of face-to-face communication as a result of social media, more than 74 percent of respondents continue to use social media during a social gathering. Use of social media sites found to be harnessing the quality of conversation. While technology facilitates instant communication, it also harms regular interaction.
\end{abstract}

Keywords: Social Media, Social Gathering, Face to Face Communication.

\section{Introduction}

McLuhan in 1964 wrote that with the rise of electronic media, "we have extended our central nervous system itself in a global embrace". McLuhan believed that the rise of electronic media marked a new phase of human history. Social media and other new media technologies are reshaping the media landscape, ushering in changes in social communication (Shankar and Ram, 2019; Wei, 2009). Smartphones and other innovative technology typically promise to make people's lives more connected, organized, and harmonious. However, the excessive and misuse of social media in everyday life confront criticism from various fields. Many people nowadays find it difficult to resist the allure of social media and other attentionseeking apps on their smartphones (Du et al., 2019). Research in the field of social psychology, one of the sub-disciplines of sociology, has shown that the excessive use of social media hinders cognitive functioning in a variety of situations, such as driving, learning in classrooms, completion of normal tasks, and overall psychological wellbeing (Ostic et al. 2021; Smith et al. 2011). Hence, using social media during face-to-face communication is often presented as harmful during a social gathering. The efficiency of youth is also harmed by spending long periods of time online on social networking sites. As a result, youths do not act naturally self-sufficient, in its place relying on the support of others (Goswami and Sharma, 2021). Such digital interaction also affects the mental health and self-esteem of youth (Asibong et al. 2020; Subrahmanyam et al. 2020).

According to Bangladesh Telecommunication Regulatory Commission (BTRC), 117.31 million internet subscribers can access the Internet anytime (BTRC, 2021). Owing to the widespread usage of social media sites and easy Internet access, there is a risk of social media addiction, which is described as the unreasonable 
and obsessive use of social media to the point that it interferes with other aspects of everyday life (Griffiths, 2000; 2012). However, this research focuses not primarily on social media addiction but rather on the impact of social media usage during a social gathering, which is also an outcome of addiction. People hardly feel hesitant to check their smartphones when the sound of notification bell rings - an eminent feature of social media. A study shows that such notifications also hurt our productivity; no wonder the effect of such notifications on social interaction during a social gathering would be inexorable (Torres, 2015). The obstreperous urge to browse to $\log$ in to social networking sites (SNSs) sites is the major cause of usage of social media during social gatherings (Chan et al., 2014). The concept of urge can be described as "a feeling of being impelled to do something" (West and Hardy, 2006). Mobile phones are getting more advanced and multifunctional, making need fulfillment in multiple facets of life convenient and feasible (Chan et al., 2014:5). The ability of technology (e.g., an Android Mobile phone) to immediately gratify instrumental (such as information seeking on Facebook) or ritualistic (needs of a companion or just passing the time) desire produces positive stimulation for consumers, which is accompanied by a desire/urge to use the technology (Greenfield, 2010). Many studies have been conducted regarding social media's effect on social interaction and face-to-face communication since the rise of cellphone and social media usage in the late 2000s. Przybylski and Weinstein (2012) stated that the advancement of communication technology facilitated instant communication and enabled billions of people to connect easily, irrespective of their distance. Yet, it is still less explored how this instant communication, as a result, affects our normal interaction in social settings. Since people associate phones with a wide variety of social networks, mobile phones may have these ubiquitous impacts. The presence of a mobile phone can cause people to worry about people and activities that are not in their immediate social context. They do so by diverting attention away from a current interpersonal interaction and into a variety of other concerns and interests (Srivastava, 2005).

Face-to-face interaction carries a particular form of social value because when two or more people join each other in maintaining a single mutual focus of cognitive and visual attention, requiring special communication privileges (Goffman, 1963). When it comes to face-to-face interactions, mobile phone addiction may make people less ready to interact. Since mobile phone addiction is associated with anxiety, which can result in a reduction in willingness to communicate (Allred and Atkin, 2020). Smartphones provide a user with an unlimited number of ways to disconnect from (those in) his immediate surroundings (Sbarra et al., 2019). Smartphones' distracting potential may not only deter people from having face-to-face interactions, but it may also expedite the end of an ongoing face-to-face conversation (Verduyn et al. 2021). Users of Social Networking Sites (SNS) such as Facebook and Instagram self-disclose by posting personal information, pictures, hobbies, and messages, according to Ledbetter et al. (2011). A user's level of selfdisclosure is proportional to their level of interdependence on others. People are more likely to disclose more personal information in social meetings or gatherings, specifically during face-to-face interaction, due to the heightened level of control within the context of social media (Walsh, Forest, and Orehek, 2020). People with poor social skills may prefer to use social media to show who they are because it gives them more control (Ledbetter et al., 2011). This may lead to a lack of communication at social gatherings, which is unquestionably harmful to interpersonal relationships.

The primary aim of this study is to understand the effect of the urge to the usage of social media during a social gathering. Though many studies have been conducted on internet addiction, social media addiction, excessive use, and problematic use of social media, this study is exclusively devoted to exploring the effect of social media usage during a social gathering. Nowadays, a global phenomenon that sums up Mobile phone addiction and problematic use of social media by a quote "Camera/Phone eats first" (Yong et al. 2020) largely affects how people used to take their meals. Similarly, it is often noted that people join social gatherings, functions, or programs just to be a part of photos and to have content/items to post on social media. The urge to take photos and posting on social media is the underlying cause of joining a function. 


\section{Objectives}

The broad objective of this study is to explore the impact of social media (e.g., Facebook, integral, etc.) on social gatherings in the Dhaka metropolitan area. The specific objectives of the study are as follows:

1. To examine how social media sites affect the interaction during a social gathering.

2. To understand respondent's perception regarding the usage of social media on a social occasion.

\section{Operationalization}

\subsection{Social Media}

Social Media is a platform that allows people to create, share or exchange information, ideas, and pictures or video. Basically, in this study Facebook, Instagram counted as the most used social media platform.

\subsection{Social Gathering}

Social gathering is defined as interactions among a diversity of individuals of all abilities in small, medium, and large groups for social and community purposes. In this study, social gathering represents meet up in a wedding ceremony, hanging out with friends, restaurants as a place for social gathering, etc.

\subsection{Face to Face Communication}

Face-to-face communication is a concept in sociology describing social interaction carried out without any devices. Goffman defined the concept as: "the reciprocal influence of individuals upon one another's actions when in one another's immediate physical presence" (1959:15).

\section{Review of Literature}

The usage of a mobile phone during a co-present face-to-face interaction is frequently portrayed as harmful to communication and self-presentation (Ictech, 2019). Goffman termed this as "cross-talk" in his work, as he stated:

Cross-talk-a conversation or conversation-like activity maintained by persons who differentially share other interaction capacities-is also possible where one member of a with momentarily sustains exclusive talk with someone who is not in the with. (Goffman 1971:25 cited in Ictech, 2019:5).

In our study, we intend to focus much on the concept of this cross-talk introduced by Goffman. In case of a cross-talk, as perceived by Goffman, might make people, who are present in a face-to-face encounter, feel "socially vulnerable and awkward when their partner participates in cross-talk" (Ictech, 2019:5). Mayne (2019) argues that one of the most unpleasant aspects is how mobile phones have taken over our life and rendered many of us inattentive to what is physically happening around us. We are rude when we disregard the individual with whom we are communicating or sending a text message on our mobile phones. Given the advantages and accessibility of social media, its extensive use and over-reliance would diminish an essential aspect of interpersonal communication in terms of affection and intimacy (Penner, 2020; Wong et al. 2017).

Because mobile phones have become so part and parcel of everyday lives, they impact the dynamics of intimate relations (Beukeboom and Pollmann, 2021), the study also found that a partner's use of their phone during co-present interactions harms relationship satisfaction. Lopez and Cuarteros (2020) focused on the effect of social media use on interpersonal communication among family members. They found that frequent usage of social media among youth decreases their personal interactions with other members of the community. Facebook, according to their findings, helps in improving interpersonal interactions among family members. They argued that Facebook [also other social media sites] provides a platform for people who struggle to communicate effectively by allowing them to communicate in a relaxed, non-threatening environment. A study by Dou et al. (2020) found that people feel closer to their partners, was more positively surprised by the conversation, and were more likely to share their contact information with their 
partners for future interactions in face-to-face interaction. In contrast, text-based interaction was found to be less intimate compared to face-to-face interaction.

It's not surprising that youths are the major users of social media sites. Mark (2018) stated that social networking sites such as Facebook, Messenger, Imo, WhatsApp, and Viber offer youth a portal for entertainment and communication, which permits consumers to keep in touch with others and reshape their daily lives live. Most people use social networking sites on their Mobile phones in Bangladesh (Reza et al., 2016). Among social media sites, Facebook is found to be frequently used by people. A study by Khurana (2015) found that 75 percent of the respondents use Facebook, and only 4 percent responded to LinkedIn. Such social networking sites also have, in their way, adversely affected the youth. The target group prefers spending an abundant amount of time on these social networking sites on an average of more than 2 hours a day which keeps them away from their purpose of existence and interacting with their natural surroundings. Their social gatherings are hampered because surfing these social networking sites keep them more involved, for which they are bound to ignore other significant social events in their lives.

Our lives have been made ostensibly easier by digital technology, but they have actually become more complicated, possibly beyond our control (Subramanian, 2017). Our social relationships have been reduced to impersonal phone calls or other forms of electronic communication. The problematic use of smartphone also makes people introvert and reluctant of interpersonal interaction (Bibi et al. 2018). A study on primary school students in Indonesia by Adrianto and Ariesta (2020) argued that there is an influence from social media on introverted behavior and interpersonal communication among Primary School students. They concluded that students who are exposed to social media sites tend to develop introverted behavior more than others.

The scale and essence of mobile phone personalization are now critical to individual identity, particularly among the youth. Often young people brag about their mobile phones to one another. Their social status is improved by the ringing tones they use and the volume and nature of messages downloaded on their mobile phones (Srivastava, 2005:128). Brignall and van Valey (2005) analyzed the effects of technology among what he said current cyber-youth - those who have grown up with the Internet as an important part of their everyday life and interaction rituals. Durkheim's concept of "totems" is relevant here to understand this statement more deeply. People consider themselves as members of certain groups, friend circles, and communities on social media sites. The pictures, statuses, selfies, and group photos shared during these communal, social gatherings, hangout, and party activities are modern-day totems. The way that social media compiles and publishes them allows for mutual recollection and reminiscence of the past event. As a result, social media achieves what Durkheim claims are necessary for sustaining the unity and solidarity that emerges from these moments of collective effervescence.

A study by Drago found that 97 percent of respondents bring their Mobile phones or tablets with them every time they leave the house, and only one respondent said they rarely do. Besides, almost 73 percent of the students in the dining hall sitting with others spent their time texting or using their social media on a smartphone (2015: 15). He further argues that overuse of social media causes in degradation of the quality of face-to-face interaction (Ibid: 16). In many social settings, people start accepting it as normal; 86.2 percent of students opined that the person they are talking to doesn't listen to them. They feel frustrated because of Phubbing and 83.3 percent of people get annoyed. Another study reported that 90 percent of respondents use their smartphones during social activity and perceived that 86 percent do the same (Ranie and Zickuhr, 2015). Social Media is also affecting relationships and feelings. A study found that 63.1 percent of people during an informal meet with friends felt that they are not important for a person who is sitting with them (Nazir, 2017).

The study of Przybylski and Weinstein (2012) found that when people use social media during a conversation, the other person reported feeling less connected and judged the quality of the conversation as poor. A study by Subramania (2017) demonstrated that social media has also changed the way that we interact, mainly the way we have lost some of our social skills. Some people are completely incapable of carrying on a normal conversation or interacting with people in person because of their dependency on 
Haque et al., Adv. J Social Sci.; Vol. 8, Issue 1, pp: 205-219, 2021

social media. Social networks are becoming one of the dominant ways we communicate. People are more obsessed with checking their smartphones every 2 minutes than engaging in meaningful conversation with their child or spouse.

All of these studies tried to explain the impact of social media in a different manner. Some of these studies explicitly dealt with the effect of social media on daily face-to-face interaction or conversation. Yet, the explicit focus on the effect of usage of social media during a social gathering has not been explored. In this study, the researcher aims to fill this gap and draw the interests of the researchers to explore more on this area of study.

\section{Methodology}

The present study aims to identify the effect of usage of social media on social gatherings in the Dhaka Metropolitan Area. This study adopted a quantitative method using a structured questionnaire survey to collect data. Respondents were selected using the purposive sampling method. The field of study was Moghbazar Dhaka, 1217 (Figure 1). Moghbazar was selected as the study area considering easy access, time limit, and availability of the research population.

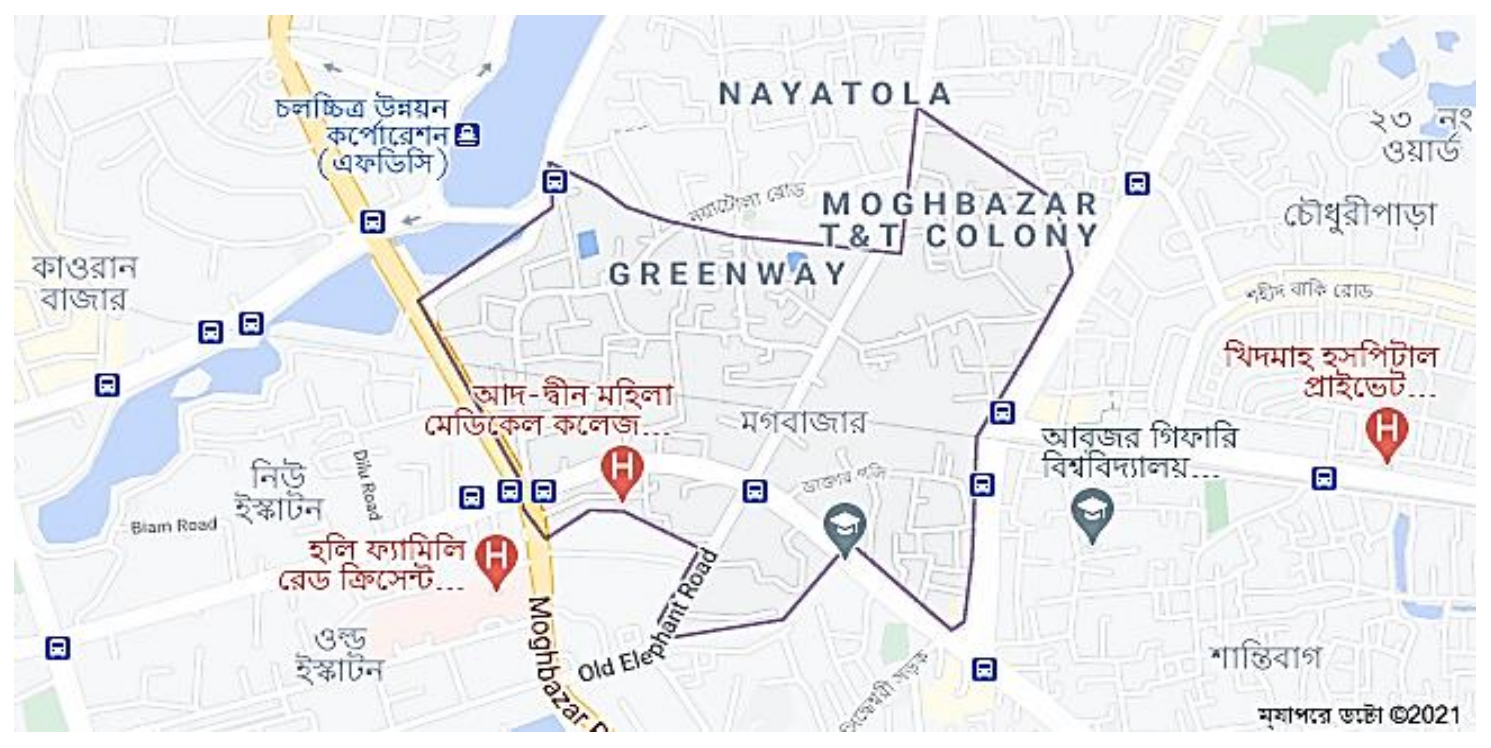

Figure 1: Study Area (Source: Google Map)

Data were collected through an online survey on 120 samples from Moghbazar using the purposive sampling method. Respondents were chosen upon meeting the criteria. The Questionnaire was set up on Google Docs form, and a link to the Questionnaire consists of 28 questions and is shared with the target population. The Questionnaire included questions addressing research objectives. Most of the questions were close-ended, limited to 2-5 options. Collected data were analyzed using Microsoft Excel. Researchers were careful about reliability and validity. Researchers conducted a pilot study and modified the Questionnaire accordingly before data collection.

Furthermore, researchers were very careful about ethical issues of social research, which is an indispensable part of research (Baker, 1999). The researcher explained the purpose of the study before collecting any information from the respondents. Respondents then had to give consent that their participation was voluntary. The respondents were informed clearly that the information they provided during the survey would be kept strictly confidential. Only the researcher would have access to the response and other study instruments. Besides, privacy during the survey process was safely guarded. The survey was held under conditions where the respondent felt most comfortable in responding openly. Also, their identity was not linked to the study at any point in time or stage of the study. It was at the respondents' discretion to participate in the survey. 


\section{Results and Analysis}

\subsection{Respondents' socio-economic and demographic characteristics}

The present study is conducted among people who live in the Moghbazar area. A total of 120 respondents' ranging from age 15 to 35 years were surveyed. Among them, 63 percent of the respondents are female and 36.7 percent of respondents are male. The sample size is skewed to female respondents due to the availability of female respondents in the study area. Table 1 reveals the demographic profiles of the respondents. The table shows that the majority of the respondents (88.3 percent) are 15-30 years old; on the contrary, a considerable number of respondents (11.7 percent) are above 30 years old. $85.8 \%$ of the respondents are Muslim where $10.8 \%$ of respondents are Hindu; comparatively the lower percentage of respondents $(1.7 \%$ each) are Christian and Buddhist.

Table 1: Socio-demographic and Economic Profile of the Respondents

\begin{tabular}{|c|c|c|}
\hline Demographics & Respondents (n) & Percentage $(\%)$ \\
\hline \multicolumn{3}{|l|}{ Age of the respondents } \\
\hline $15-30$ & 106 & 88.3 \\
\hline Above 30 & 14 & 11.7 \\
\hline \multicolumn{3}{|l|}{ Gender } \\
\hline Male & 44 & 36.7 \\
\hline Female & 76 & 63.3 \\
\hline \multicolumn{3}{|l|}{ Religion } \\
\hline Muslim & 103 & 85.8 \\
\hline Hindu & 13 & 10.8 \\
\hline Christianity & 2 & 1.7 \\
\hline Buddhist & 2 & 1.7 \\
\hline \multicolumn{3}{|c|}{ Monthly expenditure of the family } \\
\hline Below 10000 & 8 & 6.7 \\
\hline $10000-25000$ & 23 & 19.2 \\
\hline $25000-50000$ & 59 & 49.2 \\
\hline Above 50000 & 30 & 25 \\
\hline
\end{tabular}

Furthermore, table 1 shows the total monthly expenditure of respondents' families. In terms of total monthly expenditure, the majority of respondents (49.2\%) family monthly expenditure ranges BDT 2500050000 per month. A significant number of respondents $(25 \%)$ family monthly expenditure ranges above BDT 50,000 per month. Besides that, $19.2 \%$ of respondents' family monthly expenditure ranges from BDT 10,000-25,000 per month. Next section deals with the usage of social media by the respondents.

\subsection{Usage of Social media in daily life}

Figure 2 represents the respondents' amount of time spending on smartphones daily basis. It is found that, majority $(74.2 \%)$ of the respondents always use the smartphone in their daily life. On the other hand, 13.3\% of respondents use their smartphones necessarily (only when necessary). 


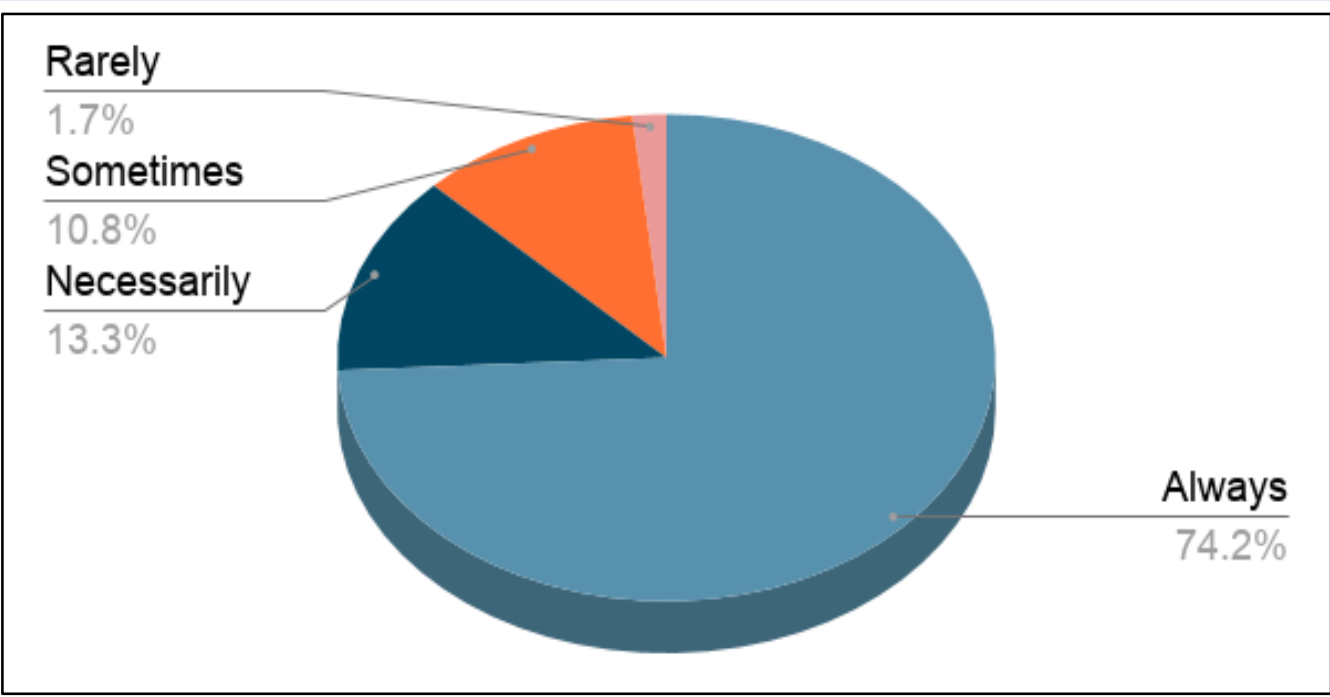

Figure 2: Respondents' amount of time spent on smartphone

On the other hand, in table 2 it is shown that the number of social media accounts in social media sites of the respondents. Here, it is highly reported that almost 65 percent of the respondents are maintaining 1-3 social media accounts. Besides, a significant number of respondents (30.8\%) use 3-5 social media sites.

Table 2: Respondents' social media accounts number

\begin{tabular}{|c|c|}
\hline Proportion & Percentage \\
\hline $1-3$ & 65 \\
\hline $3-5$ & 30.8 \\
\hline Above 5 & 4.2 \\
\hline
\end{tabular}

Figure 3 shows that the respondent amount of time spend in Facebook on average in a day. The majority of the respondents (36.7\%) reported that they usually use Facebook 2-4 hours a day, whereas 30\% respondents use Facebook for 4-6 hours a day.

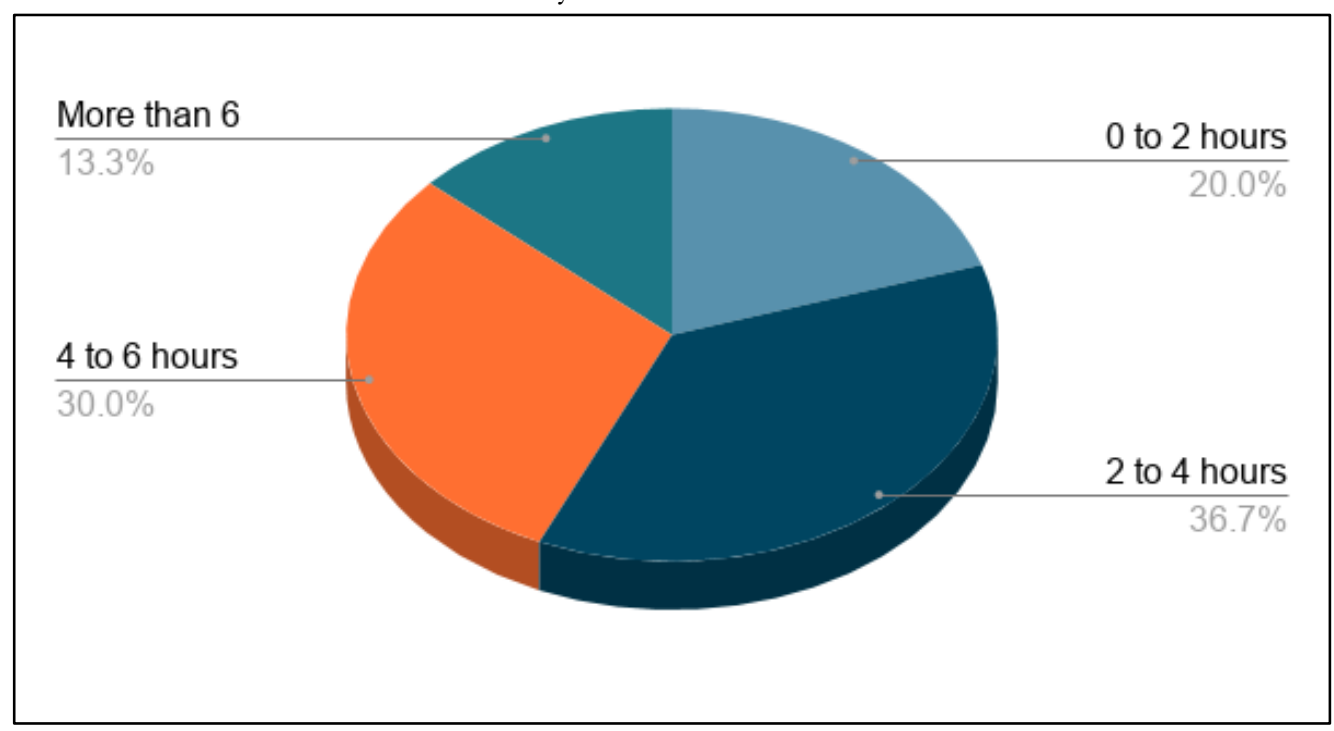

Figure 3: Respondents amount of time spent by using Facebook per day on average

Table 3 shows the specific time of using Facebook on each visit by the respondents. Almost half of the respondents (47.5\%) reported that they use Facebook for around 16-30 minutes on each visit. 20.85\% of the respondents said they use Facebook for 31 to 60 minutes or 1 hour on each visit. 
Social Media Use During Social Gathering Among Youth: A Study on Moghbazar Area of Dhaka City

Table 3: Specific time of using Facebook on average each visit by the respondents

\begin{tabular}{|l|c|}
\hline \multicolumn{1}{|c|}{ A specific time of using Facebook } & Percent \\
\hline Less than 15 minutes & 18.3 \\
\hline 16 to 30 minutes & 47.5 \\
\hline 31 to 60 minutes & 20.8 \\
\hline 1 hour to 2 hour & 10.8 \\
\hline More than 2 hour & 2.5 \\
\hline
\end{tabular}

\subsection{Social media and social gathering}

Figure 4 portrays that the respondents' joining rate in a social gathering. In a social gathering, the majority of the respondents $(55 \%)$ reported that they join in social gatherings sometimes. On the other hand, 23.3 percent of the respondents said that they always join social gatherings.

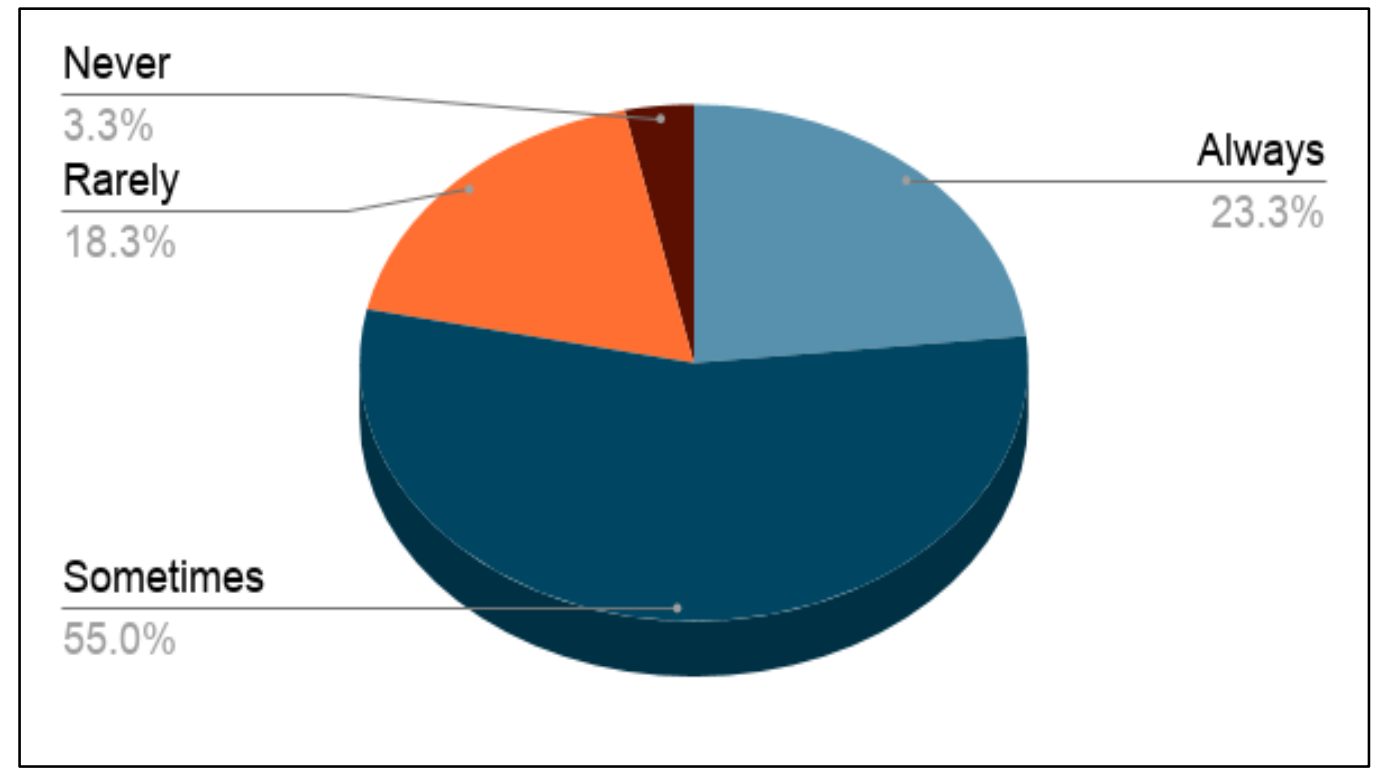

Figure 4: Respondents attending a social gathering

Table 4 shows the preference of respondents about social gathering, where the majority, 54.2 percent of the respondents, reported that they join with friends in a social gathering. A considerable 30.8 percent of the respondents said that they prefer to join social gatherings with their families.

Table 4: Respondents preference about the company in a social gathering

\begin{tabular}{|l|c|}
\hline \multicolumn{1}{|c|}{ Types } & Percent \\
\hline With friends & 54.2 \\
\hline With family & 30.8 \\
\hline With girlfriend/boyfriend & 6.7 \\
\hline With cousins & 5.8 \\
\hline With family and friends & 1.6 \\
\hline All & 0.8 \\
\hline
\end{tabular}

Table 5 shows that the majority of the respondents (87.5\%) always bring their smartphones with them when leaving for a social gathering. 43.3 percent of the respondents said that they always keep their 
Haque et al., Adv. J Social Sci.; Vol. 8, Issue 1, pp: 205-219, 2021

smartphones in their pocket during a social gathering, where a significant $39.2 \%$ of the respondents answered that they sometimes kept their smartphones in their pocket.

Table 5: Respondents using smartphone during a social gathering

\begin{tabular}{|l|c|}
\hline \multicolumn{2}{|l|}{ Respondent carrying smartphone when leaving for social gathering } \\
\hline
\end{tabular}

Table 5 also shows that the majority of the respondents (53.3\%) disagree with the statement that they join social gatherings only for taking photos. Though considerable, 19.2 percent of the respondents' reported the statement that they strongly agree with it.

\subsection{Role of social media on a social gathering}

Figure 5 shows respondents' feelings of loneliness when they attend a social gathering with their parents. Around half (48.3\%) of the respondents reported that they sometimes feel lonely when they're with their parents in a social gathering. Where $26.7 \%$ of the respondents' replied in another way; they never feel lonely when attending a gathering with their parents.

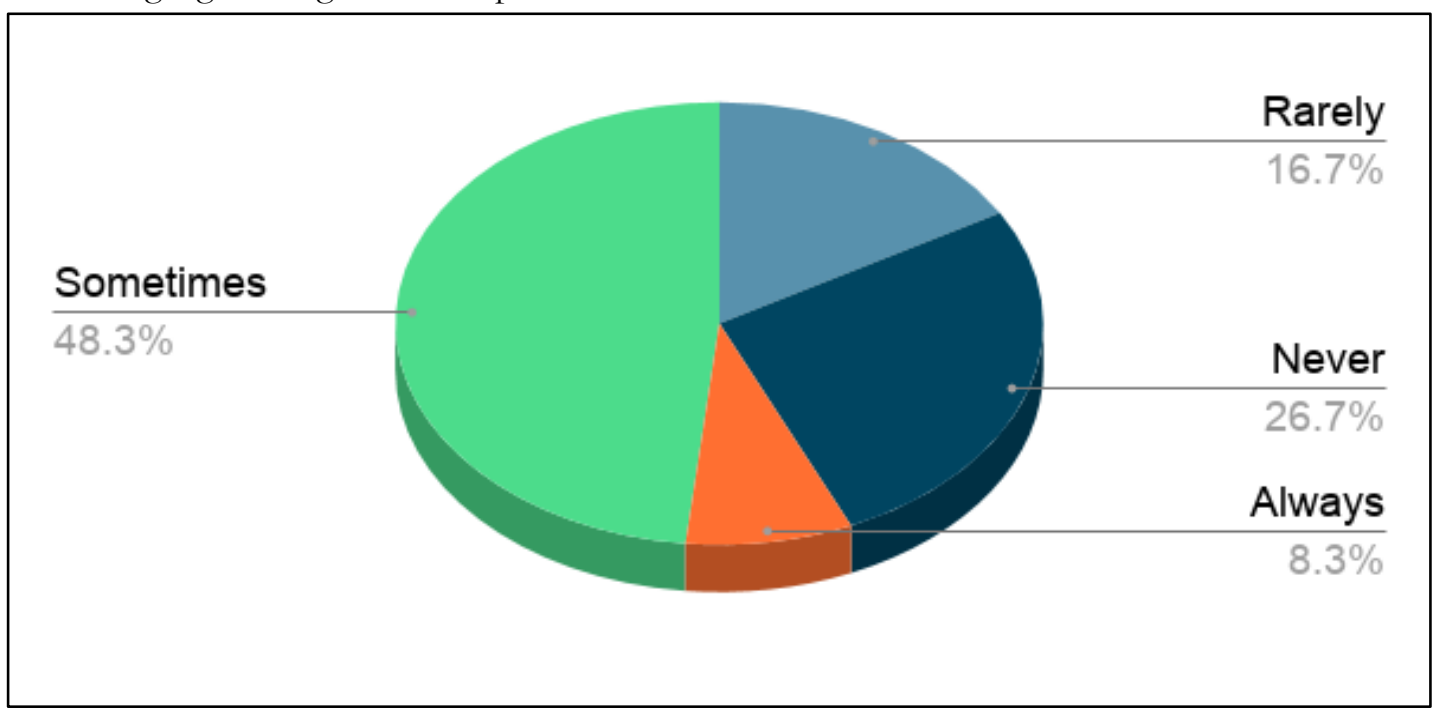

Figure 5: Respondents feeling of loneliness in a social gathering with parents 
Social Media Use During Social Gathering Among Youth: A Study on Moghbazar Area of Dhaka City

Table 6 shows that the respondents' preferences during a social gathering. The majority, 68.3 percent of the respondents, reported that they prefer talking to people in social gatherings. Considerable $14.2 \%$ of the respondents reported that they avoid face-to-face interaction in a social gathering.

Table 6: Preference about social gathering

\begin{tabular}{|c|c|}
\hline & Percent \\
\hline Talking to people & 68.3 \\
\hline Gossiping while holding the phone & 16.7 \\
\hline Avoid more face to face interaction & 14.2 \\
\hline Other & 0.8 \\
\hline
\end{tabular}

Table 7 shows that the majority of the respondents $(76.7 \%)$ tried to refrain from using social media during a social gathering. Considerable $23.3 \%$ of respondents reported not trying to refrain from using social media during a social gathering.

Table 7: View about social media on a social gathering

\begin{tabular}{|l|c|c|}
\hline Refraining from using a phone on a social gathering \\
\hline \multicolumn{3}{|c|}{ Percent } \\
\hline Yes & 76.7 \\
\hline No & 23.3 \\
\hline Using social media during any occasion or social gathering & \\
\hline & $(\mathrm{n})$ & Percent \\
\hline Yes & 89 & 74.2 \\
\hline No & 31 & 25.8 \\
\hline Social media is responsible for the lack of face-to-face interaction on a social gathering \\
\hline
\end{tabular}

Also, as table 7 shows, the majority $(74.2 \%)$ of the respondents use social media during a social gathering. And a significant number of respondents $(88.3 \%)$ think that social media is responsible for the lack of faceto-face interaction in a social gathering.

Table 8: Attributes of social media during a social gathering

Respondents' joining social gathering for being a part of the group photo

\begin{tabular}{|l|c|}
\hline & Percent \\
\hline Always & 10 \\
\hline Sometimes & 33.3 \\
\hline Rarely & 23.3 \\
\hline Never & 33.3 \\
\hline Taking photos of the food before eating & \\
\hline & Percent \\
\hline Always & 13.3 \\
\hline Sometimes & 49.2 \\
\hline Rarely & 23.3 \\
\hline Never & 14.2 \\
\hline
\end{tabular}


Haque et al., Adv. J Social Sci.; Vol. 8, Issue 1, pp: 205-219, 2021

Table 8 shows that $33.3 \%$ of respondents sometimes join the social gathering for only being a part of the group photo. It should be noted that the same 33.3 percent of the respondents reported that they never join the social gathering for being a part of the group photo. Whereas table 8 also shows that a significant number $(49.2 \%)$ of the respondents sometimes took the photo of the food before having it. $13.3 \%$ of respondents reported that they always take photos of the food before eating.

Figure 6 represents that the majority $(61.7 \%)$ of the respondents reported that social media usage on social gatherings affects interpersonal communication negatively. Besides that, 26.7 percent of the respondents reported that they strongly agreed with it.

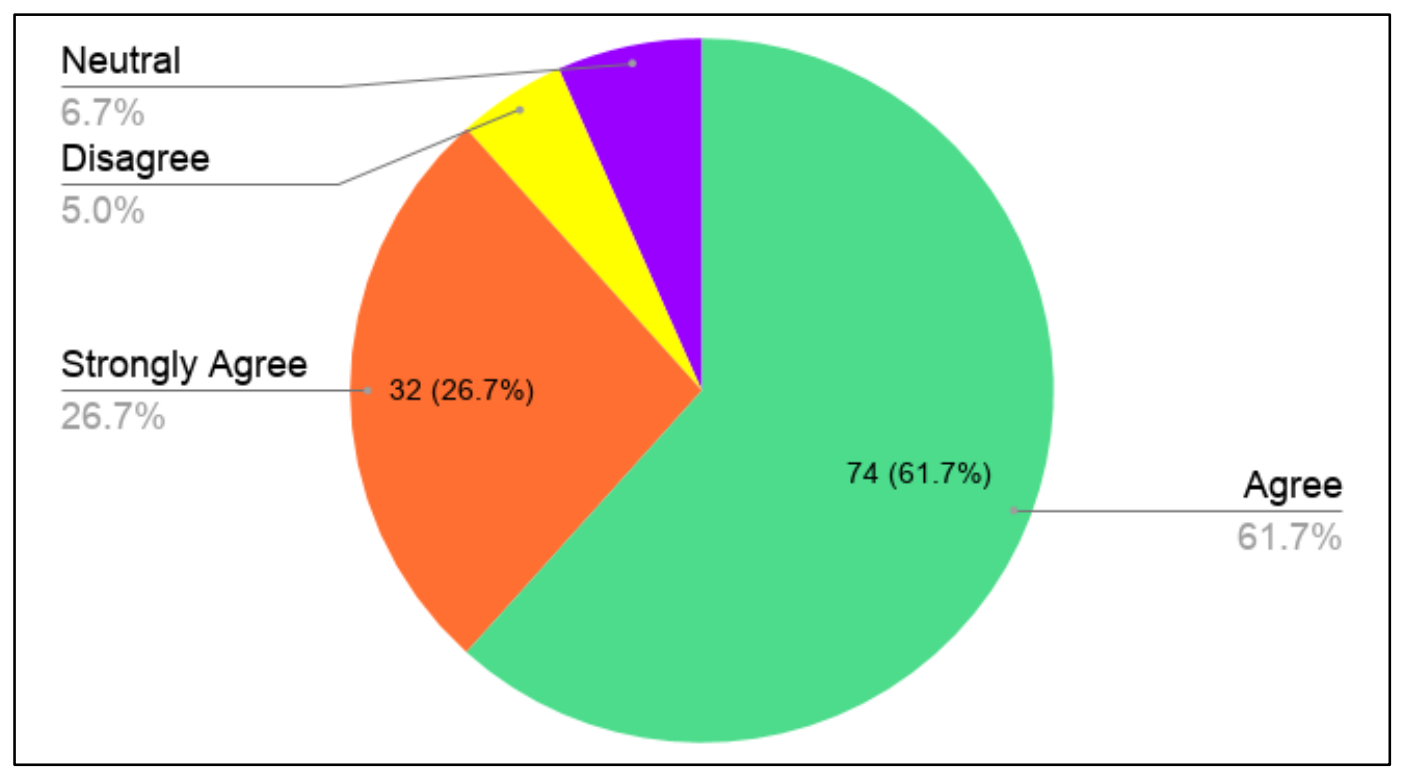

Figure 6: social gathering affecting interpersonal communication

According to figure 7, most of the respondents strongly agreed with the statement that it bothers the respondents' when his/their friends or family use social media while spending time with them. Around $90.8 \%$ of respondents agreed with the statement.

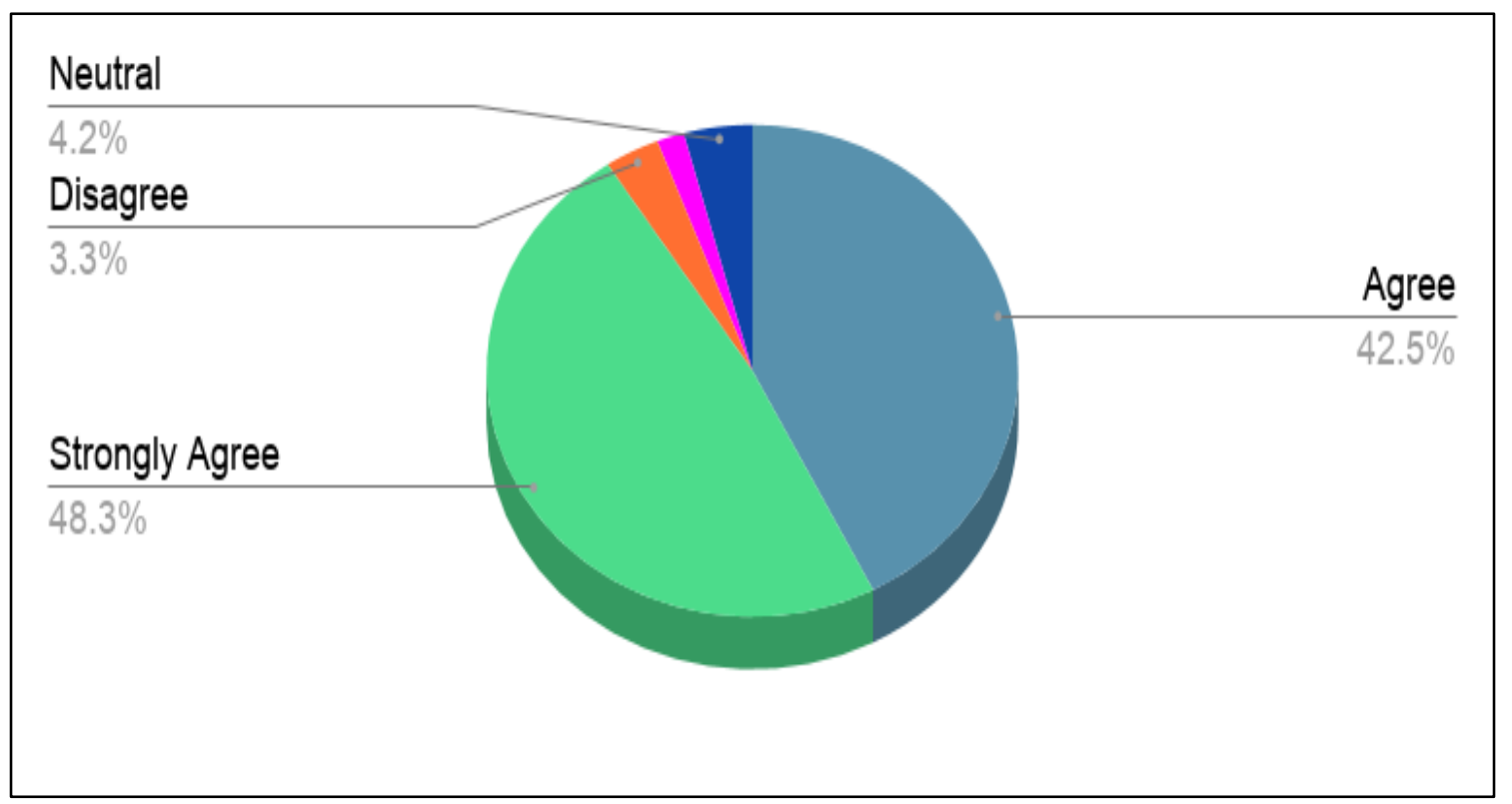

Figure 7: Being bothered by friends or family when they use social media while spending time 
Social Media Use During Social Gathering Among Youth: A Study on Moghbazar Area of Dhaka City

Figure 8 represented the respondent's level of agreement about the virtuality reshaping forms nowadays. A majority $(51.7 \%)$ of the respondents agreed with the statement of 'first camera, then fork.' Around 20.8 percent of the respondents reported that they strongly agreed with the statement.

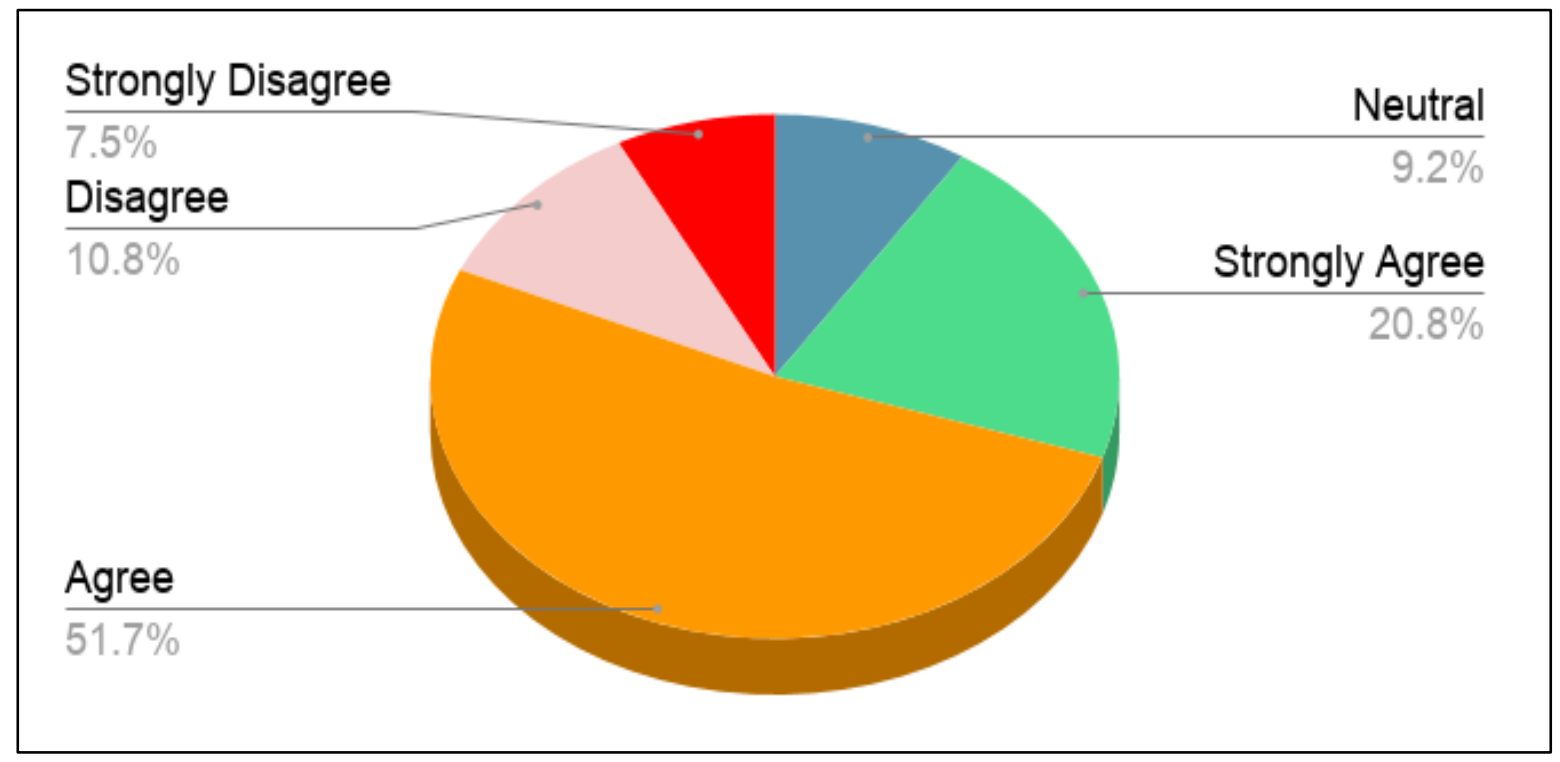

Figure 8: Respondents' level of agreement about 'First camera, then fork'

Table 8 (a) shows that respondents' level of agreement about using social media on social gatherings makes degradation the quality of conversation. A majority (48.3 percent) of the respondents agreed with the statement. Besides that, 38.3 percent of the respondents reported that they strongly agreed with the statement. Table 8 (b) shows the respondent's level of agreement about feeling isolated while attending a social gathering with parents. Around (40.8 percent) of the respondents disagreed with the statement. Besides that, 35 percent of the respondents reported that they agreed with the statement.

Table 8: Respondents' level of agreement regarding using social media during a social gathering

(a) Using social media on social gathering makes degrade the quality of conversation

\begin{tabular}{|c|c|}
\hline & Percent \\
\hline Strongly Agree & 38.3 \\
\hline Agree & 48.3 \\
\hline Disagree & 8.3 \\
\hline Neutral & 5 \\
\hline
\end{tabular}

(b) Feeling isolated when attending a social gathering with parents

\begin{tabular}{|c|c|}
\hline & Percent \\
\hline Strongly Agree & 5 \\
\hline Agree & 35 \\
\hline Disagree & 40.8 \\
\hline Strongly Disagree & 8.3 \\
\hline Neutral & 10.8 \\
\hline \multicolumn{2}{|c|}{ (c) Using social media when (someone) feels isolated } \\
\hline & percent \\
\hline Strongly Agree & 30 \\
\hline Agree & 58.3 \\
\hline Disagree & 5.8 \\
\hline Neutral & 5.8 \\
\hline
\end{tabular}


Haque et al., Adv. J Social Sci.; Vol. 8, Issue 1, pp: 205-219, 2021

Table 8 (c) shows the respondent's level of agreement about using social media on social gatherings when the respondent feels isolated. A majority ( 88.3 percent) of the respondents either strongly agreed or agreed with the statement.

\section{Conclusion}

This study aimed to analyze the pattern of social media usage among youth at a social gathering or occasion. According to the study, excessive social media use has lowered the quality of conversation. In this study, 74.2 percent of respondents said they used social media sites during a social gathering. Excessive use of social media has led to a shift in youth interaction patterns and a loss of social skills. The mobile phone has evolved into one of the most important aspects of social life, and it is no longer just a means of communication. Mobile phones are an essential part of daily life for today's cyber youth. Previously, mobile phones were thought to improve users' social status, which is still valid, but the growing importance of mobile phone services has made them more of a necessity than a luxury. People no longer require face-toface communication in many circumstances because mobile phones have so many functions. As a result, people often believe that it is unnecessary to communicate even when they are gathered for an occasion. Cross-talk was a common occurrence among the respondents (chatting with people over social media sites while being present in a social gathering). It concerns that today's youth are losing social skills such as interpersonal communication. Instead of interacting with the same people in a social gathering, many of them choose to talk or chat with them online. Many people isolate themselves in a face-to-face interaction situation due to social media's tremendous social control for users, either to disguise their weak social skills or to detach from people. The study provides insight into the role of extensive social media use in a social setting. It demonstrates that the more people use social media sites, the more likely they are to isolate themselves in social situations. According to the findings, young people should prioritize face-to-face communication and avoid using social media sites more than is essential. Uncontrolled and widespread social networking sites obliterate normal conversation and make it more artificial, resulting in the degradation of many social skills, as previously stated.

\section{Declarations}

\subsection{Study Limitation}

One of the main limitations of the study is sample size and location due to funds and other constraints. Research covering more area and a large sample size would generate a better understanding of the issue.

\subsection{Informed Consent}

Informed consent was taken from the respondent prior to the survey. No respondent was forced to participate in the study. Their participation was voluntary.

\subsection{Conflict of Interest}

The authors declare no conflict of interest.

\subsection{Publisher's Note}

AIJR remains neutral with regard to jurisdictional claims in published maps and institutional affiliations.

\section{How to Cite this Article:}

Haque, M. T., Eyemoon, E. J., \& Rahaman, A. (2021). Social Media Use During Social Gathering Among Youth: A Study on Moghbazar Area of Dhaka City. Advanced Journal of Social Science, 8(1), 205-219. https://doi.org/10.21467/ajss.8.1.205-219

\section{References}

Adrianto, K. R., \& Ariesta, F. W. (2021, March). The Effect of Social Media on Introverted Behavior and the Quality of Interpersonal Communication of Students in Primary Schools. In 1st Paris Van Java International Seminar on Health, Economics, Social Science and Humanities (PVJ-ISHESSH 2020) (pp. 151-155). 
Allred, R. J., \& Atkin, D. (2020). Cell phone addiction, anxiety, and willingness to communicate in face-to-face encounters. Communication Reports, 33(3), 95-106.

Baker, T. L. (1999). Doing Social Research, U.S.A: McGraw-Hill Inc.

Bangladesh Telecommunication Regulatory Commission (2021). License and Statistics. Dhaka: BTRC. Retrieved 15 July 2021 from: http://www.btrc.gov.bd/content/internet-subscribers-bangladesh-may-2021

Bibi, A., Bukhari, S., Sami, A., Irfan, A., \& Liaqaut, H. (2018). Effect of latest technology and social media on interpersonal communication on youth of Balochistan. Journal of Managerial Sciences, XI (3), 475-490.

Brignall, T.W., and van Valey, T. (2005). The impact of Internet communications on social interaction. Sociological Spectrum, $335-348$.

Chan D.K.S. and Cheng. G.H. (2004). A Comparison of offline and online friendship qualities at different stages of relationship development. Journal of Social and Personal Relationships. 21(3). 305-320.

Croteau, D \& Hoynes, W, (2014). Media in a Changing Global Culture. In: (ed), Media/Society: Industries, Images, and Audiences. 5th ed. United States of America: Sage Publication.

Dou, Y., Jiang, S., \& Pan, Y. (2020). Talk to Me, Don't Text Me: Face to Face Communication Generates Greater Closeness Than Texting Among Generation $\mathrm{Z}$ in China.

Drago, E. (2015). The effect of technology on face-to-face communication. Elon Journal of Undergraduate Research in Communications, 6(1).

Du, J., Kerkhof, P., \& van Koningsbruggen, G. M. (2019). Predictors of social media self-control failure: Immediate gratifications, habitual checking, ubiquity, and notifications. Cyberpsychology, Behavior, and Social Networking, 22(7), 477-485.

Durkheim, E. (1951). Suicide: a Study in Sociology. Glencoe, Illinois: American Book-Knickerbocker Press.

Faruq, M. O., Rahman, M. M., \& Alam, M. R. (2017). Impact of social networking sites in Bangladesh: Few Possible Solutions. International Journal of Intelligent Systems and Applications, 9(4), 53.

Goffman, Erving. (1959). The Presentation of Self in Everyday Life. New York: Anchor.

Goffman, Erving. (1963). Behavior in Public Places: Notes on the Social Organization of Gatherings. New York: Free Press.

Goswami, G., \& Sharma, S. (2021). Impact of Social Networking Sites on the Youth of Assam. Elementary Education Online, 20(4), 21622169.

Greenfield, D. (2010). The Addictive Properties of Internet Usage. In K.S. Young and C.N. de Abreu (Eds.), Internet addiction: A handbook and guide to evaluation and treatment. Hoboken, N.J.: John Wiley \& Sons.

Griffiths, M. D. (2000). Internet addiction: Time to be taken seriously? Addiction Research, 8, 413-418. https://doi.org/10.3109/16066350009005587

Griffiths, M. D. (2010). The role of context in online gaming excess and addiction: Some case study evidence. International Journal of Mental Health and Addiction, 8, 119-125. https://doi.org/10.1007/s11469-009-9229-x

Ictech, B. (2019). Smartphones and Face-to-Face Interaction: Digital Cross-Talk during Encounters in Everyday Life. Symbolic Interaction, 42(1), 27-45. https://doi.org/10.1002/symb.406

Khurana, N. (2015). The impact of social networking sites on the youth. J Mass Communicat Journalism, 5(12), 1-4.

Lopez, A. G., \& Cuarteros, K. G. (2020). Exploring the effects of social media on interpersonal communication among family members. Canadian Journal of Family and Youth/Le Journal Canadien de Famille et de la Jeunesse, 12(1), 66-80.

McLuhan, M. (1964[1994]). Understanding media: Extensions of Man. MIT Press.

Nazir, T. (2017). Attitude and Emotional Response among University Students of Ankara towards Phubbing. International Journal of Multidisciplinary Educational Research, 6, 11.

Ostic, D., Qalati, S. A., Barbosa, B., Shah, S. M. M., Galvan Vela, E., Herzallah, A. M., \& Liu, F. (2021). Effects of Social Media Use on Psychological Well-Being: A Mediated Model. Frontiers in Psychology, 12, 2381.

Penner, M. (2020). Mobile technologies and relationships: Rebuilding meaningful connections (Doctoral dissertation, City University of Seattle).

Przybylski, A.K., and Weinstein, N. (2012). Can you connect with me now? How the presence of mobile communication technology influences face-to-face conversation quality. Journal of Social and Personal Relationships, 1-10.

Ranie, L., and Zickuhr, K. (2015). Americans' Views on Mobile Etiquette. Washington DC: Pew Research Center. http://www.pewinternet.org/2015/08/26/americans-views-on-mobile-etiquette

Rettie, Ruth. (2009). Mobile Phone Communication: Extending Goffman to Mediated Interaction. Sociology, 43(3):421-438.

Sbarra, D. A., Briskin, J. L., \& Slatcher, R. B. (2019). Smartphones and close relationships: The case for an evolutionary mismatch. Perspectives on Psychological Science, 14(4), 596-618.

Smith, T. S., Isaak, M. I., Senette, C. G., \& Abadie, B. G. (2011). Effects of cell-phone and text-message distractions on true and false recognition. Cyberpsychology, Behavior, and Social Networking, 14(6), 351-358.

Shankar, K. S., \& Ram, K. R. (2019). Fuelling Internet growth and new media content and changing patterns of media consumption: A perspective on internet growth and new media content in India. Journal of Interdisciplinary Cycle Research. 11(10). 760-764.

Srivastava, L. (2005). Mobile phones and the evolution of social behavior. Behaviour \& Information Technology, 24, 111-129.

Strayer, D. L., Drews, F. A., \& Johnston, W. A. (2003). Cell phone-induced failures of visual attention during simulated driving. Journal of Experimental Psychology: Applied, 9, 23-32.

Subrahmanyam, K., Frison, E., \& Michikyan, M. (2020). The relation between face-to-face and digital interactions and self-esteem: A daily diary study. Human Behavior and Emerging Technologies, 2(2), 116-127.

Subramanian, K. R. (2017). Influence of social media in interpersonal communication. International Journal of Scientific Progress and Research, 38(2), 70-75.

Subramanian, K. R. (2017). Influence of social media in interpersonal communication. International Journal of Scientific Progress and Research, 38(2), 70-75.

Ten Wong, D. H., Phang, C. S., Maarop, N., Samy, G. N., Ibrahim, R., Yusoff, R. C. M., ... \& Azmi, N. F. M. (2017). Effect of Social Media on Human Interpersonal Communication: A Review. Open International Journal of Informatics (OIJI), 5(2), 1-6.

Thibaut, J. W., and Kelley, H. H. (1959). The Social Psychology of Groups. New York: Wiley. 
Haque et al., Adv. J Social Sci.; Vol. 8, Issue 1, pp: 205-219, 2021

Torres, N. (2015). Just Hearing Your Phone Buzz Hurts Your Productivity. Harvard Business Review. Retrieved 31 March 2021, from https://hbr.org/2015/07/just-hearing-your-phone-buzz-hurts-your-productivity.

Vanden Abeele, M. M. P., Antheunis, M. L., and Schouten, A. P. (2016). The effect of mobile messaging during a conversation on impression formation and interaction quality. Computers in Human Behavior, 62, 562-569. https://doi.org/10.1016/j.chb.2016.04.005

Verduyn, P., Schulte-Strathaus, J. C., Kross, E., \& Hülsheger, U. R. (2021). When do smartphones displace face-to-face interactions and what to do about it?. Computers in Human Behavior, 114, 106550.

Wei, R. (2009). The state of new media technology research in China: A review and critique. Asian Journal of Communication. 19 (1), pp.116-127.

Walsh, R. M., Forest, A. L., \& Orehek, E. (2020). Self-disclosure on social media: the role of perceived network responsiveness. Computers in Human Behavior, 104, 106162.

West, R. and Hardy, A. (2006). Theory of Addiction. Malden, MA: Blackwell Pub./Addiction Press

Yong, J., Tong, E., \& Liu, J. (2020). When the camera eats first: Exploring how meal-time cell phone photography affects eating behaviours. Appetite, 154. https://doi.org/10.1016/j.appet.2020.104787

Publish your research article in AlJR journalsOnline Submission and Tracking

Peer-Reviewed

Rapid decision

Immediate Publication after acceptance

Articles freely available online

Retain full copyright of your article.

Submit your article at journals.aijr.org
Publish your books with AIJR publisher-

$\checkmark \quad$ Publish with ISBN and DOI.

$\checkmark$ Publish Thesis/Dissertation as Monograph.

$\checkmark$ Publish Book Monograph.

$\checkmark$ Publish Edited Volume/ Book.

$\checkmark$ Publish Conference Proceedings

$\checkmark$ Retain full copyright of your books.

Submit your manuscript at books.aijr.org 